\title{
Predicting the occurrence of alate aphids in Brassicaceae
}

\author{
Francisco Jorge Cividanes ${ }^{(1)}$ and Terezinha Monteiro dos Santos-Cividanes ${ }^{(2)}$
}

\begin{abstract}
(1)Universidade Estadual Paulista, Faculdade de Ciências Agrárias e Veterinárias, Departamento de Fitossanidade, Via de Acesso Prof. Paulo Donato Castellane, s/no, CEP 14884-900 Jaboticabal, SP, Brazil. E-mail: fjcivida@fcav.unesp.br (2)Agência Paulista de Tecnologia dos Agronegócios, Centro Leste, Avenida Bandeirantes, no 2.419, Vila Virgínia, CEP 14030-670 Ribeirão Preto, SP, Brazil. E-mail: terezinha@apta.sp.gov.br
\end{abstract}

\begin{abstract}
The objective of this work was to predict the occurrence of alates of Brevicoryne brassicae, Lipaphis erysimi, and Myzus persicae (Hemiptera, Aphididae) in Brassicaceae. The alate aphids were collected in yellow water traps from July 1997 to August 2005. Aphid population peaks were predicted using a degree-day model. The meteorological factors, temperature, air relative humidity, rainfall, and sunshine hours, were used to provide precision indexes to evaluate the best predictor for the date of the first capture of alate aphids by the traps. The degree-day model indicated that the peak population of the evaluated aphid species can be predicted using one of the following biofix dates: January $1^{\text {st }}$, June $1^{\text {st }}$, and the date of the first capture of the alate aphid species by the yellow water traps. The best predictor of $B$. brassicae occurrence is the number of days with minimum temperature $>15^{\circ} \mathrm{C}$, and of $L$. erysimi and $M$. persicae, the number of days with rainfall occurrence.

Index terms: Brassica oleracea, pest management, population dynamics, thermal requirements.

\section{Previsão da ocorrência de pulgões alados em Brassicaceae}

Resumo - O objetivo deste trabalho foi prever a ocorrência de formas aladas de Brevicoryne brassicae, Lipaphis erysimi e Myzus persicae (Hemiptera, Aphididae) em Brassicaceae. Os pulgões foram coletados com armadilhas tipo bandeja amarela com água, no período de julho de 1997 a agosto de 2005. Os picos populacionais dos pulgões foram previstos com uso de modelo de graus-dias. Os fatores meteorológicos temperatura, umidade relativa do ar, precipitação pluvial e insolação foram utilizados para a obtenção de índices de precisão para determinar o melhor previsor da data da primeira captura de pulgões alados pelas armadilhas. O modelo de graus-dias indicou que o pico populacional dessas espécies de pulgões pode ser previsto ao se utilizar uma das seguintes datas biofix: primeiro de janeiro, primeiro de junho e data da primeira captura de alados das espécies de pulgão por armadilha tipo bandeja amarela com água. O melhor previsor da ocorrência de $B$. brassicae é o número de dias com temperatura mínima $>15^{\circ} \mathrm{C}$, e de L. erysimi e $M$. persicae, o número de dias com ocorrência de chuvas.
\end{abstract}

Termos para indexação: Brassica oleracea, manejo de pragas, dinâmica populacional, exigências térmicas.

\section{Introduction}

The aphids Brevicoryne brassicae (Linnaeus), Lipaphis erysimi (Kaltenbach), and Myzus persicae (Sulzer) (Hemiptera, Aphididae) are worldwide distributed and can damage several crops, and transmit viruses to plants (Emden \& Harrington, 2007). Brevicoryne brassicae is associated to plants of the Brassicaceae family (Dixon, 1998). Lipaphis erysimi has been observed in several plant species, such as lettuce (Stoltz et al., 1996), potato (DiFonzo et al., 1997), watercress (Blackman \& Eastop, 2000), and Brassicaceae (Blande et al., 2004), whereas $M$. persicae is a generalist species infesting more than
400 plant species (Francis et al., 2006). The control of these aphids has often been done using insecticides (Dewar, 2007).

Meteorological factors, especially temperature, are the main environmental variables acting on aphids, associated to the occurrence of population peaks (Dixon, 1998; Tang et al., 1999; Asin \& Pons, 2001). Several authors (Chattopadhyay et al., 2005; Zamani et al., 2006; Klueken et al., 2009) have predicted aphid occurrence by meteorological factors.

Degree-day models relate insect development to environmental temperature and do not operate on a calendar-day basis but on physiological time, which considers a degree-day as a unit (Gomez et al., 2009).

Pesq. agropec. bras., Brasília, v.47, n.4, p.505-510, abr. 2012 
Degree-day models have been used to predict the occurrence of insects, such as aphids (Hanula et al., 2002; Chakravarty \& Gautam, 2004; Gomez et al., 2009), helping to improve the decisions associated with pest control in integrated pest management programs (Day \& Knight, 1995).

According to Chattopadhyay et al. (2005), for an efficient, economical, and ecological control of aphids, it is necessary to determine the right timing of attack in relation to weather factors, which may enable the prediction of insect occurrence and allow growers to take timely action for efficient crop management.

The objective of this work was to predict the occurrence of alates of $B$. brassicae, L. erysimi, and $M$. persicae using a degree-day model and meteorological indexes.

\section{Materials and Methods}

The experiment was carried out at the College of Agrarian and Veterinary Sciences (FCAV) of the Universidade Estadual Paulista (Unesp), Jaboticabal, SP, Brazil $\left(21^{\circ} 15^{\prime} 22^{\prime \prime} \mathrm{S}, 48^{\circ} 18^{\prime} 58^{\prime \prime} \mathrm{W}\right)$. The traps were set up in an area composed of a fodder plant collection and were located at least $200 \mathrm{~m}$ from Brassicaceae plants.

The population survey was done at weekly intervals from July 1997 to August 2005. The alate aphids were captured using two yellow water traps, spaced $10 \mathrm{~m}$ apart and kept at $120 \mathrm{~cm}$ above ground level, according to Gutierrez et al. (1974). The traps were $36 \mathrm{~cm}$ in diameter and contained approximately $12 \mathrm{~L}$ of water, $5.0 \mathrm{~mL}$ of detergent, and $50 \mathrm{~mL}$ of formaldehyde. The insects were removed from the traps using a thin mesh screen and transported to the laboratory where the alate aphids were preserved in $80 \%$ ethanol for later identification.

At the beginning of the experiment, winged specimens of B. brassicae, L. erysimi, and M. persicae were used to identify, by comparison, the aphid specimens captured during the experiment.

The occurrence of population peaks was predicted using a degree-day model, according to Silveira Neto et al. (1976). This model requires the lower developmental thermal threshold (Tb) of the insect and the maximum and minimum temperatures of the environment to calculate the number of degree-days. The following thermal requirements of the aphid biological cycles (nymph to adult) were considered in the model: $B$. brassicae, $\mathrm{Tb}=4.5^{\circ} \mathrm{C}$ and $\mathrm{K}$ (thermal constant) $=176.1$ degree-day $($ Cividanes, 2003); L. erysimi, $\mathrm{Tb}=3.04^{\circ} \mathrm{C}$ and $\mathrm{K}=132.2$ degree-day (Godoy \& Cividanes, 2001); and M. persicae, $\mathrm{Tb}=2.23^{\circ} \mathrm{C}$ and $\mathrm{K}=165.6$ degree-day (Cividanes $\&$ Souza, 2003). The counting of degree-days by the model was started on the following biofix dates: date of the first capture of the alate aphid species by the yellow water traps, January $1^{\text {st }}$, and June $1^{\text {st }}$. This last biofix date was chosen because the cultivation of Brassicaceae plants is concentrated from June to September in the region of Jaboticabal, SP, Brazil.

The prediction of aphid occurrence was evaluated by comparing the dates of population peaks predicted by the model to dates of peaks observed in the field (Cividanes \& Santos-Cividanes, 2010). The differences in days (lags) between the dates of the predicted peaks and the ones observed in the field indicate the accuracy of the prediction. Only lags common to the three biofix dates were used to compare predictions. Results were subjected to analysis of variance, and means were compared by the Tukey test, at $5 \%$ probability.

Daily meteorological factors collected at the weather station of FCAV/Unesp, located at approximately $500 \mathrm{~m}$ from the yellow water traps, were used to investigate the capacity of several meteorological indexes to predict the capture date of the first alate aphid species by the yellow water traps between 1998 and 2005, according to Zhang et al. (1997). The variables used were: day of the year; accumulated degree-days from January $1^{\text {st }}$ of each year using the base threshold temperatures of the aphid species; number of days in which the maximum daily temperature was greater than 20,25 , and $30^{\circ} \mathrm{C}$ from January $1^{\text {st }}$ to the date of the catch; number of days in which the average daily temperature was greater than 15,20 , and $25^{\circ} \mathrm{C}$ from January $1^{\text {st }}$ to the date of the catch; number of days in which the minimum daily temperature was greater than 10,15 , and $20^{\circ} \mathrm{C}$ from January $1^{\text {st }}$ to the date of the catch; number of days in which the air relative humidity was greater than 60 , 70 , and $80 \%$ from January $1^{\text {st }}$ to the date of the catch; number of days in which sunshine hours were greater than 2, 6, and 10 hours from January $1^{\text {st }}$ to the date of the catch; number of days with rainfall from January $1^{\text {st }}$ to the date of the catch; and number of days without rainfall from January $1^{\text {st }}$ to the date of the catch. 
For the eight-year evaluation period, the mean and standard error were calculated for each of the variables, and the standard error:mean ratio was used as an index of precision to evaluate the best predictor.

\section{Results and Discussion}

The differences in number of days (lags) between the prediction by the degree-day model and the population peak of B. brassicae, L. erysimi, and M. persicae in the field were not significant between the three biofix dates (Table 1). These results indicate that the occurrence of alates can be predicted with equal accuracy using any of the biofix dates to start the counting of degree-days.

Although degree-day models are used to predict the occurrence of aphids and other insect pests (Zou et al., 2004; Hansen, 2006), the time lags observed between the prediction and actual occurrence can range from zero to nine days (Hickel et al., 2003; Jiao et al., 2006). Differences between prediction and occurrence dates of an insect population peak in the field can be related to the difficulty of determining the biofix date, which is considered important to get an accurate prediction by the model (Knight \& Light, 2005).

The prediction of the occurrence of an aphid population peak with the degree-day model can be obtained using preferentially June $1^{\text {st }}$ as a biofix date for $B$. brassicae, January $1^{\text {st }}$ for L. erysimi, and the date of the first capture of alates by traps for $M$. persicae (Table 1). However, since the lags between the predictions by the degree-day model and the population peaks observed in the field were not significant among the three biofix dates, it is possible to use any of the biofix dates to predict the occurrence of population peaks of B. brassicae, L. erysimi, and M. persicae.
The dates of the first capture of the alate $B$. brassicae by the yellow water traps occurred on May, June, and September, whereas for L. erysimi and M. persicae the dates were concentrated in the beginning of the year, i.e., January and February. According to Cividanes \& Santos-Cividanes (2010), the occurrence of the alate B. brassicae was restricted from May to October-November, and no specimens were captured from December to April of the following year. However, the alates L. erysimi and M. persicae were observed for a longer period than B. brassicae, especially L. erysimi, which was captured in most of the evaluated months.

The number of days with minimum temperature greater than $15^{\circ} \mathrm{C}$ was the best predictor of $B$. brassicae, and the standard error:mean ratio was 0.0413 (Table 2). The mean number of days with minimum temperature above $15^{\circ} \mathrm{C}$ for the first catch over the eight-year period was 138 with a range of $113-159$. The next best predictor (standard error: mean ratio $=0.0545$ ) was the number of days with an average temperature greater than $20^{\circ} \mathrm{C}$ (number of days $=147$, range $=120-178$ ).

The best predictor (standard error:mean ratio $=0.0793$ ) for the date of the first capture of the alate $L$. erysimi by yellow traps was the number of days with rainfall (Table 2), and the mean number of days with this environmental feature was 43 (range $=26-57$ days). The second best predictor (standard error:mean ratio $=0.1094$ ) was the number of days with air relative humidity greater than $80 \%$ (number of days $=39$, range $=20-51$ ). The prediction of $L$. erysimi related to environmental humidity is in agreement with Chattopadhyay et al. (2005), who linked the appearance of $L$. erysimi in Brassicaceae with the occurrence of air relative humidity above $75 \%$.

Table 1. Mean \pm standard error of the difference between the dates of the prediction and occurrence of population peaks in the field by the degree-day model using three biofix dates for aphid species ${ }^{(1)}$.

\begin{tabular}{|c|c|c|c|c|}
\hline \multirow[t]{2}{*}{ Species } & \multicolumn{3}{|c|}{ Biofix dates } & \multirow[t]{2}{*}{ Mean } \\
\hline & $1^{\text {st }}$ capture of alates in traps & January $1^{\text {st }}$ & June $1^{\text {st }}$ & \\
\hline \multirow[t]{2}{*}{ Brevicoryne brassicae } & $3.03 \pm 0.28 \mathrm{a}$ & $2.79 \pm 0.30 \mathrm{a}$ & $2.21 \pm 0.23 \mathrm{a}$ & $2.68 \pm 0.27$ \\
\hline & $(-5 \text { to }+5)^{(2)}$ & $(-5$ to +5$)$ & $(-4$ to +4$)$ & $(-5$ to +5$)$ \\
\hline \multirow[t]{2}{*}{ Lipaphis erysimi } & $1.61 \pm 0.16 \mathrm{a}$ & $1.41 \pm 0.14 \mathrm{a}$ & $1.76 \pm 0.17 \mathrm{a}$ & $1.59 \pm 0.16$ \\
\hline & $(-4$ to +4$)$ & $(-4$ to +4$)$ & $(-4$ to +3$)$ & $(-4$ to +4$)$ \\
\hline \multirow[t]{2}{*}{ Myzus persicae } & $2.05 \pm 0.20 \mathrm{a}$ & $2.39 \pm 0.20 \mathrm{a}$ & $2.25 \pm 0.22 \mathrm{a}$ & $2.23 \pm 0.21$ \\
\hline & $(-4$ to +5$)$ & $(-5$ to +4$)$ & $(-5$ to +5$)$ & $(-5$ to +5$)$ \\
\hline
\end{tabular}

${ }^{(1)}$ Means followed by equal letters, in the rows, do not differ by the Tukey test, at $5 \%$ probability. ${ }^{(2)}$ Range, in days, between the dates of the prediction and occurrence of population peaks in the field. The signs (-) or $(+)$ indicate, respectively, the date before or after a population peak occurrence. 
In relation to the alate $M$. persicae, the best predictor (standard error:mean ratio $=0.0372$ ) of the date of the first capture was the number of days with rainfall (number of days $=56$, range $=42-60)($ Table 2$)$. The next best predictor (standard error:mean ratio $=0.0373$ ) was the number of days with air relative humidity greater than $70 \%$ (number of days $=103$, range $=85-113$ ).

Considering the best predictors of alate aphids, predictors related to temperature prevailed for $B$. brassicae and to humidity for $L$. erysimi and $M$. persicae. These species also showed the same predictor, i.e., number of days with rainfall. This result is in accordance with Cividanes \& Santos-Cividanes (2010), which reported that L. erysimi and M. persicae showed similar flight dynamics, differing from $B$. brassicae. These authors also found that $B$. brassicae showed a significant correlation with maximum and minimum temperatures, sunshine hours, and air relative humidity, whereas $L$. erysimi and $M$. persicae were only affected by sunshine and relative humidity.

The use of traps can enable the prediction of the appearance of alate aphids in Brassicaceae depending on weather conditions (Debaraj \& Singh, 1996). The present study predicted the first capture of alates of

Table 2. Indexes from standard error:mean ratio of variables calculated annually from January $1^{\text {st }}$ until the date of the first capture of the alate aphid species by yellow traps.

\begin{tabular}{lccc}
\hline Variable ${ }^{(1)}$ & Brevicoryne brassicae & Lipaphis erysimi & Myzus persicae \\
\hline $\mathrm{N}$ & 0.0982 & 0.1285 & 0.0490 \\
$\mathrm{DD}$ & 0.0868 & 0.1238 & 0.0424 \\
$\mathrm{P}$ & 0.0608 & 0.0793 & 0.0372 \\
$\mathrm{~A}$ & 0.1212 & 0.1948 & 0.0746 \\
Tmax $\left({ }^{\circ} \mathrm{C}\right)$ & & & \\
$\quad>20$ & 0.0983 & 0.1495 & 0.0540 \\
$>25$ & 0.0799 & 0.1510 & 0.0471 \\
$>30$ & 0.0593 & 0.1731 & 0.0560 \\
Tmed $\left({ }^{\circ} \mathrm{C}\right)$ & & & \\
$>15$ & 0.0951 & 0.1495 & 0.0539 \\
$>20$ & 0.0545 & 0.1376 & 0.0410 \\
$>25$ & 0.1132 & 0.1739 & 0.1175 \\
Tmin $\left({ }^{\circ} \mathrm{C}\right)$ & & & \\
$>10$ & 0.0914 & 0.1469 & 0.0527 \\
$>15$ & 0.0413 & 0.1334 & 0.0380 \\
$>20$ & 0.0692 & 0.1283 & 0.1097 \\
RH $(\%)$ & & & \\
$>60$ & 0.0843 & 0.1441 & 0.0494 \\
$>70$ & 0.0847 & 0.1202 & 0.0373 \\
$>80$ & 0.0772 & 0.1094 & 0.0534 \\
Sunshine & & & \\
$>2$ hours & 0.1037 & 0.1716 & 0.0531 \\
$>6$ hours & 0.1030 & 0.2137 & 0.0681 \\
$>10$ hours & 0.1394 & 0.2096 & 0.1232 \\
\hline
\end{tabular}

${ }^{(1)} \mathrm{N}$, number of days of the year; $\mathrm{DD}$, accumulated degree-days; P and A, number of days with and without rainfall, respectively. Tmax, Tmed, Tmin, maximum, average, and minimum temperatures; $\mathrm{RH}$, air relative humidity; Sunshine, sunshine hours.
$B$. brassicae, L. erysimi, and M. persicae with yellow water traps, which indicated that the early occurrence of alates can be predicted by the number of days with minimum temperature above $15^{\circ} \mathrm{C}$ (B. brassicae) and the number of days with rainfall ( $L$. erysimi and $M$. persicae). These predictors are useful for the management of these aphid species, because they can indicate the best starting time for aphid sampling or even for control applications in Brassicaceae.

It should be emphasized that the degree-day model and the indicators selected in the present study should also be validated for use on other crops, besides Brassicaceae, and in different regions, other than Jaboticabal. This procedure is necessary since the variation between regions related to the occurrence of aphid biotypes and the specific conditions in the crop that favor the insect pest can alter meteorological factors for aphid prediction (Chattopadhyay et al., 2005).

\section{Conclusions}

1. The prediction of the occurrence of alates of Brevicoryne brassicae, Lipaphis erysimi, and Myzus persicae can be obtained using a degree-day model and the following biofix dates: January $1^{\text {st }}$, June $1^{\text {st }}$, and the date of the first capture of the alates by the yellow water traps.

2. Considering the meteorological indexes, the best predictor of the alate $B$. brassicae is the number of days with minimum temperature $>15^{\circ} \mathrm{C}$, and of $L$. erysimi and $M$. persicae, the number of days with rainfall occurrence.

\section{Acknowledgements}

To Dr. José Carlos Barbosa from the College of Agrarian and Veterinary Sciences of the Universidade Estadual Paulista (Unesp), for help in the statistical analysis; to Dr. Carlos Roberto Sousa e Silva from the Universidade Federal de São Carlos, for the identification of the aphid species; to Alex Antonio Ribeiro, José Altamiro de Souza, and José Luiz Dacal Seguim from the College of Agrarian and Veterinary Sciences of Unesp, for their assistance in collecting data for the experiment; and to Conselho Nacional de Desenvolvimento Científico e Tecnológico, for the scholarship granted. 


\section{References}

ASIN, L.; PONS, X. Effect of high temperature on the growth and reproduction of corn aphids (Homoptera: Aphididae) and implications for their population dynamics on the northeastern Iberian peninsula. Environmental Entomology, v.30, p.1127-1134, 2001.

BLACKMAN, R.L.; EASTOP, V.F. Aphids on the world's crops: an identification and information guide. $2^{\text {nd }}$ ed. Chichester: John Wiley and Sons, 2000. 476p.

BLANDE, J.D.; PICKETT, J.A.; POPPY, G.M. Attack rate and success of the parasitoid Diaeretiella rapae on specialist and generalist feeding aphids. Journal of Chemical Ecology, v.30, p.1781-1795, 2004.

CHAKRAVARTY, N.V.K.; GAUTAM, R.D. Degree-day based forewarning system for mustard aphid. Journal of Agrometeorology, v.6, p.215-222, 2004.

CHATTOPADHYAY, C.; AGRAWAL, R.; KUMAR, A.; SINGH, Y.P.; ROY, S.K.; KHAN, S.A.; BHAR, L.M.; CHAKRAVARTHY, N.V.K.; SRIVASTAVA, A.; PATEL, B.S.; SRIVASTAVA, B.; SINGH, C.P.; MEHTA, S.C. Forecasting of Lipaphis erysimi on oilseed Brassicas in India - a case study. Crop Protection, v.24, p.1042-1053, 2005.

CIVIDANES, F.J. Exigências térmicas de Brevicoryne brassicae e previsão de picos populacionais. Pesquisa Agropecuária Brasileira, v.38, p.561-566, 2003.

CIVIDANES, F.J.; SANTOS-CIVIDANES, T.M. dos. Ocorrência de formas aladas de pulgões e a relação com fatores meteorológicos e plantas hospedeiras. Pesquisa Agropecuária Brasileira, v.45, p.7-15, 2010.

CIVIDANES, F.J.; SOUZA, V.P. Exigências térmicas e tabelas de vida de fertilidade de Myzus persicae (Sulzer) (Hemiptera: Aphididae) em laboratório. Neotropical Entomology, v.32, p.413-419, 2003.

DAY, R.K.; KNIGHT, J.D. Operational aspects of forecasting migrant insect pests. In: DRAKE, V.A.; GATEHOUSE, A.G. (Ed.). Insect Migration: tracking resources through space and time. Cambridge: Cambridge University, 1995. p.323-334.

DEBARAJ, Y.; SINGH, T.K. Aerial population fluctuation of cabbage aphid, Brevicoryne brassicae (L.). Annals of Agricultural Research, v.17, p.308-310, 1996.

DEWAR, A.M. Chemical control. In: EMDEN, H.F. van; HARRINGTON, R. (Ed.). Aphids as crop pests. Wallingford: CAB International, 2007. p.391-422.

DIFONZO, C.D.; RAGSDALE, D.W.; RADCLIFFE, E.B.; GUDMESTAD, N.C.; SECOR, G.A. Seasonal abundance of aphid vectors of potato virus $\mathrm{Y}$ in the Red River Valley of Minnesota and North Dakota. Journal of Economic Entomology, v.90, p.824-831, 1997.

DIXON, A.F.G. Aphid ecology: an optimization approach. $2^{\text {nd }}$ ed. London: Chapman and Hall, 1998. 300p.

EMDEN, H.F. van; HARRINGTON, R. (Ed.). Aphids as crop pests. Wallingford: CAB International, 2007. 717p.
FRANCIS, F.; GERKENS, P.; HARMEL, N.; MAZZUCCHELLI, G.; PAUW, E.; HAUBRUGE, E. 2006. Proteomics in Myzus persicae: effect of aphid host plant switch. Insect Biochemistry and Molecular Biology, v.36, p.219-227, 2006.

GODOY, K.B.; CIVIDANES, F.J. Exigências térmicas e previsão de picos populacionais de Lipaphis erysimi (Kalt.) (Homoptera: Aphididae). Neotropical Entomology, v.30, p.369-371, 2001.

GOMEZ, N.N.; VENETTE, R.C.; GOULD, J.R.; WINOGRAD, D.F. A unified degree day model describes survivorship of Copitarsia corruda Pogue \& Simmons (Lepidoptera: Noctuidae) at different constant temperatures. Bulletin of Entomological Research, v.99, p.65-72, 2009.

GUTIERREZ, A.P.; NIX, H.A.; HAVENSTEIN, D.E.; MOORE, P.A. The ecology of Aphis craccivora Koch and subterranean clover stunt virus in South-East Australia. III. A regional perspective of the phenology and migration of the cowpea aphid. Journal of Applied Ecology, v.11, p.21-35, 1974.

HANSEN, L.M. Models for spring migration of two aphid species Sitobion avenae (F.) and Rhopalosiphum padi (L.) infesting cereals in areas where they are entirely holocyclic. Agricultural and Forest Entomology, v.8, p.83-88, 2006.

HANULA, J.L.; DEBARR, G.L.; WEATHERBY, J.C.; BARBER, L.R.; BERISFORD, C.W. Degree-day model for timing insecticide applications to control Dioryctria amatella (Lepidoptera: Pyralidae) in loblolly pine seed orchards. The Canadian Entomologist, v.134, p.255-268, 2002.

HICKEL, E.R.; VILELA, E.F.; SOUZA, O.F.F.; MIRAMONTES, O. Previsão da atividade de vôo de Grapholita molesta (Busk) em pomares de pessegueiro e ameixeira, através do ajuste entre captura de adultos em armadilhas de feromônio e acumulação de calor. Revista de Ciências Agroveterinárias, v.2, p.30-41, 2003.

JIAO, X.; XUAN, W.; SHENG, C. A forecasting model for emergence and flight pattern of the overwintering generation of Chilo suppressalis (Lepidoptera: Pyralidae) based on pheromone trap catches and degree-days in northeastern China. Acta Entomologica Sinica, v.49, p.705-709, 2006.

KLUEKEN, A.M.; HAU, B.; ULBER, B.; POEHLING, H.M. Forecasting migration of cereal aphids (Hemiptera: Aphididae) in autumn and spring. Journal of Applied Entomology, v.133, p.328-344, 2009.

KNIGHT, A.L.; LIGHT, D.M. Timing of egg hatch by earlyseason codling moth (Lepidoptera: Tortricidae) predicted by moth catch in pear ester- and codlemone-baited traps. The Canadian Entomologist, v.137, p.728-738, 2005.

SILVEIRA NETO, S.; NAKANO, O.; BARBIN, D.; VILLA NOVA, N.A. Manual de ecologia dos insetos. São Paulo: Ceres, 1976. $419 \mathrm{p}$

STOLTZ, R.L.; GAVLAK, R.G.; HALBERT, S. Aphids associated with lettuce (Lactuca sativa L.) in the Matanuska Valley, Alaska. Journal of Vegetable Crop Production, v.2, p.35-45, 1996.

TANG, Y.Q.; LAPOINTE, S.L.; BROWN, L.G.; HUNTER, W.B. Effects of host plant and temperature on the biology of Toxoptera citricida (Homoptera: Aphididae). Environmental Entomology, v.28, p.895-900, 1999. 
ZAMANI, A.A.; TALEBI, A.A.; FATHIPOUR, Y.; BANIAMERI, $\mathrm{V}$. Effect of temperature on biology and population growth parameters of Aphis gossypii Glover (Hom., Aphididae) on greenhouse cucumber. Journal of Applied Entomology, v.130, p.453-460, 2006.

ZHANG, J.; DRUMMOND, F.A.; LIEBMAN, M.; HARTKE, A. Phenology and dispersal of Harpalus rufipes DeGeer (Coleoptera:
Carabidae) in agroecosystems in Maine. Journal of Agricultural Entomology, v.14, p.171-186, 1997.

ZOU, L.; STOUT, M.J.; RING, D.R. Degree-day models for emergence and development of the rice water weevil (Coleoptera: Curculionidae) in southwestern Louisiana. Environmental Entomology, v.33, p.1541-1548, 2004.

Received on March 27, 2011 and accepted on January 16, 2012 